\title{
ANALISIS KETERAMPILAN DASAR MENGAJAR MAHASISWA CALON GURU BIOLOGI DI PENDIDIKAN BIOLOGI FKIP UAD
}

\author{
Hani Irawati ${ }^{1}$ \\ ${ }^{1}$ Univesitas Ahmad Dahlan, Yogyakarta, 55191 \\ Email Korespondensi: hani@pbio.uad.ac.id
}

Diajukan: 1 January 2020; Diterima: 2 February 2020; Diterbitkan: 30 April 2020

\begin{abstract}
Abstrak: Penelitian ini bertujuan untuk mengetahui tingkat keterampilan dasar mengajar mahasiswa prodi pendidikan biologi FKIP UAD tahun akademik 2018-2019 yang mengambil mata kuliah micro teaching. Adapun keterampilan yang ingin dilihat yaitu: 1) keterampilan membuka pelajaran, 2) keterampilan menjelaskan, 3) keterampilan memberi penguatan, 4) keterampilan mengadakan variasi, 5) keterampilan membimbing diskusi, 6) keterampilan mengelola kelas, 7) keterampilan bertanya, dan 8) keterampilan menutup pelajaran. Penelitian ini merupakan penelitian kuantitatif dengan menggunakan populasi seluruh mahasiswa prodi pendidikan biologi FKIP UAD angkatan 2016 yang mengambil mata kuliah micro teaching. Penentuan sampel penelitian menggunkan teknik purposive random sampling, sampling penelitian terdiri atas mahasiswa micro teaching kelas A, D, E, F, dan J yang berjumlah 65 mahasiswa. Teknik pengumpulan data dengan menggunakan observasi dan instrumen pengumpulan data dengan menggunakan lembar observasi. Data dianalisis secara deskriptif kuantitatif. Hasil penelitian menunjukkan bahwa: keterampilan dasar mengajar mahasiswa calon guru program studi pendidikan biologi FKIP UAD berada dalam kategori sangat baik pada aspek membuka pelajaran, bertanya, dan menutup pelajaran. Kategori baik pada aspek penguasaan kelas, menjelaskan, dan memberikan penguatan. Kategori cukup pada aspek melakukan variasi, dan kategori kurang pada aspek memimpin diskusi kelompok kecil.
\end{abstract}

Kata Kunci: keterampilan dasar mengajar, calon guru biologi

\begin{abstract}
This study aims to determine the level of basic teaching skills for Biology Education Study Program students of FKIP UAD for the academic year 2018-2019 who take micro teaching courses. The skills to look at are: 1) opening lesson skills, 2) explaining skills, 3) reinforcement skills, 4) variation skills, 5) discussion guiding skills, 6) classroom management skills, 7) questioning skills, and 8) closing skills. This research is a quantitative study using a population of all students of biology education study program FKIP UAD class of 2016 who take micro teaching courses. Determination of the research sample using purposive random sampling technique, the research sampling consisted of 65 students of micro teaching classes $A, D, E, F$, and J. Data collection techniques using observation and data collection instruments using observation sheets. Data were analyzed descriptively quantitatively. The results showed that: the basic teaching skills of prospective teachers of the biology education study program FKIP UAD were in the very good category in the aspects of opening lessons, asking questions, and closing lessons. Good category on aspects of class mastery, explaining, and providing reinforcement. The category is sufficient on the aspect of doing variations, and the category is less on the aspect of leading small group discussions.
\end{abstract}

Keywords: basic teaching skills, prospective biology teacher

\section{Pendahuluan}

Guru merupakan suatu jabatan profesi, sehingga untuk menjadi guru perlu dilatih dan disiapkan secara khusus. Sesuai dengan undang-undang no 14 tahun 2005 tentang guru dan dosen pada bab VI pasal 3 disebutkan bahwa kompetensi yang harus dimiliki oleh seorang guru meliputi kompetensi pedagogi, kompetensi kepribadian, kompetensi profesional, dan kompetensi sosial. Kompetensi pedagogi mengharuskan seorang guru untuk mampu melaksanakan proses pembelajaran dengan baik. Untuk dapat melakukan proses pembelajaran dengan baik seorang guru harus memiliki keterampilan dasar mengajar yang baik pula.

Keterampilan dasar mengajar yang baik akan membuat pembelajaran lebih efektif dan peserta didik akan lebih aktif dalam proses pembelajaran (Mika, 2016). Keterampilan dasar mengajar merupakan keterampilan umum mengajar sebagai bekal utama dalam pelaksanaan tugas profesional yang mengacu 
atau merujuk kepada konsep pendekatan kompetensi dari LPTK (Fitri, 2017). Keterampilan dasar mengajar yang harus dikuasai oleh guru antara lain adalah: keterampilan membuka pelajaran, menjelaskan, mengadakan variasi, bertanya, memberikan penguatan, memimpin diskusi kelompok kecil, mengelola kelas, memberikan penguatan, dan menutup pelajaran (Shoffan, 2017).

Keterampilan dasar mengajar merupakan keterampilan spesifik yang harus dimiliki oleh setiap guru agar dapat melaksanakan tugas mengajar secara efektif, efisien, dan profesional. Mengingat pentingnya keterampilan mengajar dalam menentukan kualitas proses pembelajaran yang akan dilaksanakan oleh mahasiswa calon guru, maka penguasaan keterampilan dasar mengajar tidak cukup hanya dihafalkan secara teoritis namun, harus dilatihkan secara kontinu melalui matakuliah-matakuliah yang ada (Putri, 2017). Keterampilan dasar mengajar dapat dilatih kepada mahasiswa calon guru biologi pada program studi pendidikan biologi FKIP UAD melalui pembelajaran mikro (microteaching). Microteaching merupakan model pelatihan bagi calon guru untuk dapat menguasai keterampilan dasar mengajar tertentu melalui proses pengajaran yang sederhana, dilakukan di dalam ruangan khusus dengan praktikan secara bergantian bermain peran menjadi pengajar dan teman-temannya menjadi siswa (Shoffan, 2017). Mata kuliah microteaching merupakan mata kuliah yang wajib ditempuh oleh mahasiswa program studi pendidikan biologi UAD pada semester VI dengan bobot 2sks dan dilakukan secara praktik bukan teori.

Penelitian ini bertujuan untuk mendeskripsikan keterampilan dasar mengajar mahasiswa calon guru biologi pada program studi pendidikan biologi FKIP UAD selama menempuh matakuliah microteaching. Hasil penelitian ini dapat menjadi informasi yang penting untuk mengembangkan keterampilan dasar mengajar mahasiswa pada tahapan real teaching pada mata kuliah selanjutnya yaitu mata kuliah program pengalaman lapangan (PLP).

\section{Metode Penelitian}

Penelitian ini merupakan jenis penelitian deskriptif. Penelitian deskriptif menurut Sugiyono (2006) merupakan penelitian yang dilakukan untuk mengetahui nilai variabel mandiri, baik satu variabel atau lebih (independen) tanpa membandingkan atau menghubungkan dengan variabel lainnya. Pada penelitian ini, hanya dipaparkan data yang diperoleh dari hasil penilaian kinerja ( performance ) selama mengikuti matakuliah microteaching untuk selanjutnya diinterpretasikan.

Penelitian dilakukan pada program studi pendidikan biologi FKIP UAD pada semester genap tahun akademik 2018/2019. Populasi merupakan wilayah generalisasi yang terdiri atas obyek atau subyek yang mempunyai kualitas dan karakter tertentu untuk ditetapkan bagi yang meneliti agar bias dipelajari dan kemudian ditarik kesimpulannya (Sugiyono, 2013). Populasi pada penelitian ini adalah seluruh mahasiswa pendidikan biologi UAD yang mengambil mata kuliah microteching tahun akademik 2018/2019 kelas A-J yang berjumlah 148 mahasiswa. Sampel adalah bagian dari jumlah dan karakteristik yang dimiliki populasi (Sugiyono, 2013). Sampel pada penelitian ini ditentukan dengan teknik purposive random sampling, sehingga diperoleh lima kelas sebagai sampel yaitu kelas A, D, E, F, dan J dengan jumlah 65 mahasiswa.

Teknik pengumpulan data dengan observasi dan instrumen yang digunakan untuk mengumpulkan data dengan menggunakan lembar observasi. Data dianalisis secara deskriptif kuantitatif. Data yang diperoleh dari lembar observasi keterampilan dasar mahasiswa pada matakuliah microteaching dikalkulasikan dan kemudian dikategorikan agar skor yang diperoleh menjadi bermakna sesuai dengan pendapat Arikunto (2013) yaitu dengan kategori seperti pada tabel berikut ini: Tabel 1. Rentang skor penilaian

\begin{tabular}{ccc}
\hline No & Rentang skor & Kategori \\
\hline 1. & $<60$ & Kurang \\
\hline 2. & $60-70$ & Cukup \\
\hline 3. & $71-80$ & Baik \\
\hline 4. & $>80$ & Sangat Baik \\
\hline
\end{tabular}




\section{Hasil Penelitian dan Pembahasan}

\section{Hasil Penelitian}

Tabel 2. Hasil observasi keterampilan dasar mengajar

\begin{tabular}{|c|c|c|c|}
\hline No & Aspek & $\begin{array}{c}\text { Rerata skor } \\
\text { yang } \\
\text { diperoleh }\end{array}$ & Kategori \\
\hline 1 & $\begin{array}{l}\text { Keterampilan } \\
\text { membuka pelajaran }\end{array}$ & $80 \%$ & $\begin{array}{c}\text { Sangat } \\
\text { baik }\end{array}$ \\
\hline 2 & $\begin{array}{l}\text { Keterampilan } \\
\text { mengelola kelas }\end{array}$ & $76 \%$ & Baik \\
\hline 3 & $\begin{array}{l}\text { Keterampilan } \\
\text { menjelaskan }\end{array}$ & $73 \%$ & Baik \\
\hline 4 & $\begin{array}{l}\text { Keterampilan } \\
\text { bertanya }\end{array}$ & $82 \%$ & $\begin{array}{c}\text { Sangat } \\
\text { baik }\end{array}$ \\
\hline 5 & $\begin{array}{l}\text { Keterampilan } \\
\text { membimbing diskusi } \\
\text { kelompok kecil }\end{array}$ & $51 \%$ & Kurang \\
\hline 6 & $\begin{array}{l}\text { Keterampilan } \\
\text { mengadakan } \\
\text { penguatan }\end{array}$ & $71 \%$ & Baik \\
\hline 7 & $\begin{array}{l}\text { Keterampilan } \\
\text { mengadakan variasi }\end{array}$ & $67 \%$ & Cukup \\
\hline 8 & $\begin{array}{l}\text { Keterampilan } \\
\text { menutup pelajaran }\end{array}$ & $89 \%$ & $\begin{array}{c}\text { Sangat } \\
\text { baik }\end{array}$ \\
\hline & Rerata & $73.63 \%$ & Baik \\
\hline
\end{tabular}

Hasil keterampilan masing-masing aspek ditampilkan pada tabel 3 sampai dengan tabel 10

$\underline{\text { Tabel 3. Hasil observasi aspek keterampilan membuka pelajaran }}$

\begin{tabular}{llcc}
\hline No & Indikator & $\begin{array}{c}\text { Skor rerta } \\
\text { diperoleh }\end{array}$ & Kategori \\
\hline 1 & Menarik Perhatian & $75 \%$ & Baik \\
\hline 2 & $\begin{array}{l}\text { Menimbulkan } \\
\text { motivasi }\end{array}$ & $73 \%$ & Baik \\
\hline 3 & Memberi acuan & $85 \%$ & $\begin{array}{c}\text { Sangat } \\
\text { Baik }\end{array}$ \\
\hline 4 & Membuat kaitan & $87 \%$ & $\begin{array}{c}\text { Sangat } \\
\text { baik }\end{array}$ \\
\hline & Rerata & $\mathbf{8 0 \%}$ & $\begin{array}{c}\text { Sangat } \\
\text { Baik }\end{array}$ \\
\hline & & &
\end{tabular}

\begin{tabular}{llcc}
\multicolumn{3}{c}{ Tabel 4 Hasil observasi aspek keterampilan mengelola kelas } \\
\hline No & Indikator & $\begin{array}{c}\text { Skor rerta } \\
\text { diperoleh }\end{array}$ & Kategori \\
\hline 1 & Keantusiasan & $80 \%$ & $\begin{array}{c}\text { Sangat } \\
\text { baik }\end{array}$ \\
\hline 2 & Tingkah laku guru & $78 \%$ & Baik \\
\hline 3 & $\begin{array}{l}\text { Mendorong peserta } \\
\text { didik untuk disiplin }\end{array}$ & $70 \%$ & Baik \\
\hline & Rerata & $\mathbf{7 6 \%}$ & Baik \\
\hline
\end{tabular}

Tabel 5 Hasil observasi aspek keterampilan menjelaskan

\begin{tabular}{llcc}
\hline No & Indikator & $\begin{array}{l}\text { Skor rerta } \\
\text { diperoleh }\end{array}$ & Kategori \\
\hline 1 & $\begin{array}{l}\text { Penggunaan metode } \\
\text { pembelajaran }\end{array}$ & $66 \%$ & Cukup \\
\hline 2 & Ketepatan materi & $80 \%$ & $\begin{array}{c}\text { Sangat } \\
\text { Baik }\end{array}$ \\
\hline
\end{tabular}

\begin{tabular}{|c|c|c|c|}
\hline 3 & $\begin{array}{l}\text { Penguasaan } \\
\text { kompetensi }\end{array}$ & $73 \%$ & Baik \\
\hline & Rerata & $73 \%$ & Baik \\
\hline
\end{tabular}

Tabel 6 Hasil observasi aspek keterampilan bertanya

\begin{tabular}{llcc}
\hline No & Indikator & $\begin{array}{c}\text { Skor rerta } \\
\text { diperoleh }\end{array}$ & Kategori \\
\hline 1 & $\begin{array}{l}\text { Pengungkapan } \\
\text { pertanyaan secara } \\
\text { jelas dan singkat }\end{array}$ & $85 \%$ & $\begin{array}{c}\text { Sangat } \\
\text { baik }\end{array}$ \\
\hline 2 & $\begin{array}{l}\text { Pemberian } \\
\text { acuan/petunjuk }\end{array}$ & $84 \%$ & $\begin{array}{c}\text { Sangat } \\
\text { Baik }\end{array}$ \\
\hline 3 & Pemindahan giliran & $75 \%$ & Baik \\
\hline 4 & Penyebaran & $75 \%$ & Baik \\
\hline 5 & $\begin{array}{l}\text { Pemberian waktu } \\
\text { berfikir }\end{array}$ & $79 \%$ & Baik \\
\hline 6 & Pemberian tuntunan & $80 \%$ & $\begin{array}{c}\text { Sangat } \\
\text { baik }\end{array}$ \\
\hline & Rerata & $\mathbf{8 2 \%}$ & $\begin{array}{c}\text { Sangat } \\
\text { Baik }\end{array}$ \\
\hline
\end{tabular}

Tabel 7 Hasil Observasi aspek keterampilan membimbing diskusi kelompok kecil

\begin{tabular}{llcc}
\hline No & Indikator & $\begin{array}{l}\text { Skor rerta } \\
\text { diperoleh }\end{array}$ & Kategori \\
\hline 1 & $\begin{array}{l}\text { Memusatkan perhatian } \\
\text { peserta didik }\end{array}$ & $68 \%$ & Cukup \\
\hline 2 & Memperluas masalah & $50 \%$ & Kurang \\
\hline 3 & $\begin{array}{l}\text { Menganalisis pendapat } \\
\text { peserta didik }\end{array}$ & $45 \%$ & Kurang \\
\hline 4 & $\begin{array}{l}\text { Meluruskan alur } \\
\text { berpikir peserta didik }\end{array}$ & $47 \%$ & Kurang \\
\hline 5 & $\begin{array}{l}\text { Memberikan } \\
\text { kesempatan peserta } \\
\text { didik untuk } \\
\text { berpartisipasi }\end{array}$ & $49 \%$ & Kurang \\
\hline 6 & Menutup diskusi & $40 \%$ & Kurang \\
\hline \multicolumn{2}{c}{ Rerata } & $\mathbf{5 1 \%}$ & Kurang \\
\hline
\end{tabular}

Tabel 8 Hasil observasi aspek keterampilan mengadakan penguatan

\begin{tabular}{llcc}
\hline No & Indikator & $\begin{array}{l}\text { Skor rerta } \\
\text { diperoleh }\end{array}$ & Kategori \\
\hline 1 & $\begin{array}{l}\text { Penguatan kepada } \\
\text { peserta didik tertentu }\end{array}$ & $62 \%$ & Cukup \\
\hline 2 & $\begin{array}{l}\text { Penguatan kepada } \\
\text { kelompok }\end{array}$ & $75 \%$ & Baik \\
\hline 3 & $\begin{array}{l}\text { Pemberian penguatan } \\
\text { dengan segera }\end{array}$ & $76 \%$ & Baik \\
\hline$\quad$ Rerata & $\mathbf{7 1 \%}$ & Baik \\
\hline
\end{tabular}

$\underline{\text { Tabel } 9 \text { Hasil observasi aspek keterampilan mengadakan variasi }}$

\begin{tabular}{llcc}
\hline No & Indikator & $\begin{array}{c}\text { Skor rerta } \\
\text { diperoleh }\end{array}$ & Kategori \\
\hline 1 & $\begin{array}{l}\text { Variasi dalam } \\
\text { mengajar }\end{array}$ & $73 \%$ & Baik \\
\hline 2 & $\begin{array}{l}\text { Variasi dalam } \\
\text { penggunaaan media } \\
\text { pembeljaaran }\end{array}$ & $70 \%$ & Baik \\
\hline
\end{tabular}




\begin{tabular}{|c|c|c|c|}
\hline 3 & $\begin{array}{l}\text { Variasi dalam pola } \\
\text { interaksi dan kegiatan } \\
\text { peserta didik }\end{array}$ & $57 \%$ & Kurang \\
\hline & Rerata & $67 \%$ & Cukup \\
\hline \multicolumn{4}{|c|}{ Tabel 10 Hasil observasi aspek keterampilan menutup pelajaran } \\
\hline No & Indikator & $\begin{array}{c}\text { Skor rerta } \\
\text { diperoleh }\end{array}$ & Kategori \\
\hline 1 & $\begin{array}{l}\text { Meninjau kembali } \\
\text { penguasaan inti } \\
\text { pelajaran }\end{array}$ & $89 \%$ & $\begin{array}{c}\text { Sangat } \\
\text { baik }\end{array}$ \\
\hline 2 & Mengevaluasi & $90 \%$ & $\begin{array}{c}\text { Sangat } \\
\text { baik }\end{array}$ \\
\hline 3 & $\begin{array}{l}\text { Penialian dan } \\
\text { refleksi }\end{array}$ & $88 \%$ & $\begin{array}{c}\text { Sangat } \\
\text { baik }\end{array}$ \\
\hline 4 & $\begin{array}{l}\text { Menyampaikan } \\
\text { materi yang akan } \\
\text { datang }\end{array}$ & $89 \%$ & $\begin{array}{l}\text { Sangat } \\
\text { baik }\end{array}$ \\
\hline & Rerata & $89 \%$ & $\begin{array}{c}\text { Sangat } \\
\text { baik }\end{array}$ \\
\hline
\end{tabular}

\section{Pembahasan}

Keterampilan dasar mengajar merupakan keterampilan yang bersifat khusus yang harus dimiliki oleh guru dan calon guru agar dapat melaksanakan tugas mengajar secara efektif, efisien, dan profesional (Mulyatun, 2014). Terdapat 8 jenis keterampilan dasar mengajar yang harus dikuasai oleh seorang calon guru yaitu: keterampilan membuka pelajaran, mengelola kelas, menjelaskan, bertanya, membimbing diskusi kelompok kecil, mengadakan penguatan, mengadakan variasi, dan menutup pelajaran.

Berdasarkan penelitian yang telah dilakukan terlihat bahwa secara keseluruhan mahasiswa calon guru biologi pada program studi pendidikan biologi FKIP UAD yang mengambil mata kuliah micro teaching telah memiliki keterampilan dasar mengajar dengan rerata skor $73.63 \%$ atau berkategori baik. Walaupun sudah berkategori baik, akan tetapi ada beberapa aspek yang masih berkategori cukup dan kurang, sehingga setelah selesai microteaching masih perlu dilakukan perbaikan-perbaikan dan latihan-latihan secara kontinu.

\section{Keterampilan membuka pelajaran}

Pada aspek keterampilan membuka pelajaran mahasiswa mendapatkan kategori sangat baik, hal ini menujukkan bahwa mahasiswa sudah mampu untuk memulai suatu proses pembelajaran dengan sangat baik, walaupun pada indikator memberikan motivasi dan menarik perhatian masih perlu ditingkatkan. Keterampilan membuka pelajaran menurut peraturan menteri pendidikan dan kebudayaan no 22 tahun 2016 mencakup apersepsi, orientasi, dan motivasi. Kegiatan membuka pelajaran bertujuan untuk menyiapkan mental peserta didik dalam menghadapi topik pelajaran baru yang dilandasi oleh pengetahuan dan pengalmaan yang telah dimiliki sebelumnya.

Keterampilan membuka pelajaran merupakan awal keberhasilan seorang guru dalam melaksanakan proses pembelajaran. Keterampilan membuka pelajaran yang baik akan menimbulkan motivasi dan kemauan serta ketertarikan siswa dalam belajar (Siswanto, 2010). Membuka pelajaran dengan baik dapat mendorong siswa untuk belajar dan sangat menentukan termotivasi tidaknya siswa dalam mengikuti pelajaran (Mulyatun, 2014). Jika pembelajran diawali dengan pembukaan yang baik maka seluruh proses dalam kegiatan pembelajaran sampai akhir akan dapat berjalan dengan baik pula.

\section{Keterampilan mengelola kelas}

Mahasiswa program studi pendidikan biologi FKIP UAD pada aspek mengelola kelas mendapatkan kategori baik. Keterampilan mengelola kelas pada dasarnya adalah usaha yang dilakukan oleh guru agar tercapai kondisi optimal yang memungkinkan terlaksananya proses pembelajaran yang efektif dan efisien. Menurut Woolfolk (Mulyatun, 2014) keberhasilan guru dalam pembelajaran disamping ditentukan oleh pengetahuan guru tentang bahan ajar dan metode mengajar juga ditentukan oleh pengelolaan kelas. Oleh karena itu, kemampuan guru dalam mengelola kelas menjadi hal yang sangat penting karena berkaitan langsung dengan aktivitas belajar siswa di dalam kelas.

Seorang guru biologi harus mampu untuk mengelola kelas dengan baik yaitu menciptakan dan mempertahankan kondisi belajar optimal bagi tercapainya tujuan pembelajaran. Pada saat mahasiswa calon guru melakukan micro teaching dalam mengelola kelas indicator yang masih perlu ditingkatkan yaitu tentang kedisiplinan. Mahasiswa calon guru belum mampu membuat siswa memiliki sikap disiplin yang baik. Adakalanya siswa datang terlambat tidak mendapatkan teguran, begitu juga dengan siswa yang tidak tepat 
waktu dalam mengerjakan maupun mengumpulkan tugas tidak mendapatkan peringatan yang tegas.

\section{Keterampilan menjelaskan}

Keterampilan menjelaskan calon guru biologi mendapatkan kategori baik, hal ini menunjukkan bahwa pada saat proses pembelajaran mahasiswa calon guru sudah mampu mentransfer materi ajar dengan baik. Menjelaskan merupakan suatu kegiatan mengorganisasikan materi pelajaran dalam tata aturan yang terencana secara sistematis, sehingga dengan mudah dapat dipahami oleh siswa. Hal ini sesuai dengan pendapat Uzer (2006) bahwa menjelaskan adalah usaah penyajian materi pembelajaran yang diorganisir secara sistematis.

Kemampuan seorang guru dalam menjelaskan materi akan sangat berdampak terhadap pemahaman materi yang dikuasai oleh siswa. Jika guru tidak mampu menjelaskan materi pembelaajran dengan baik dan benar, makan bisa saja terjadi miskonsepsi. Pada saat menjelaskan materi pembelajaran guru harus mampu untuk memilih metode apa yang akan digunakan dengan cara menyesuaikan dengan karakteristik peserta didik dan karakteristik materi pembelajrannya.

\section{Keterampilan bertanya}

Keterampilan bertanya sangat diperlukan dan harus dikuasai oleh seorang guru. Proses pembelajaran tidak dapat lepas dari kegiatan tanya jawab baik antara guru dan siswa atau sebaliknya. Oleh karena itu, keterampilan bertanya merupakan bagian yang tidak terpisahkan dalam rangka meningkatkan kualitas proses dan hasil pembelajaran yang sekaligus merupakan bagian dari keberhasilan dalam pengelolaan kelas. Bertanya dapat diartikan sebagai kegiatan pengajar dalam menyampaikan pertanyaan kepada peserta didik dalam proses pembelajaran baik pertanyaan dasar maupun pertanyaan lanjut. Bertanya merupakan salah satu aktivitas yang selalu ada dalam proses komunikasi. Dalam proses pembelajaran bertanya memainkan peranan penting sebab pertanyaan merupakan jantung pembelajaran.

Mahasiswa calon guru mendapatkan kategori sangat baik dalam aspek bertanya. Hal ini menunjukkan bahwa mahasiswa sudah mampu untuk memberikan pertanyaan dengan bahasa yang mudah dipahami oleh siswa sehingga siswa mampu dengan baik menjawab pertanyaan yang diberikan oleh guru. Pertanyaan yang tersusun dengan baik dan teknik penyampaian yang tepat akan memberikan dampak positif terhadap siswa (Shoffan, 2016).

\section{Keterampilan membimbing diskusi kelompok kecil}

Keterampilan membimbing diskusi kelompok kecil mendapatkan kategori yang paling rendah diantara seluruh aspek keterampilan dasar mengajar. Pada aspek ini mahasiswa calon guru belum mampu secara optimal untuk menempatkan diri pada saat terjadi diskusi kelompok kecil. Mahasiswa calon guru cenderung hanya terpaku pada satu kelompok saja dan kelompok yang lain terabaikan.

Penguasaan keterampilan memimpin diskusi kelompok kecil menuntut guru untuk memposisikan diri sebagai organisator kegiatan pembelajaran, sumber informasi bagi siswa, pendorong siswa untuk belajar, pendiagnosa dan pemberi bantuan kepada siswa sesuai dengan kebutuhannya. Diskusi kelompok kecil dapat berjalan secara efektif dan efisien jika guru mampu memposisikan dirinya dengan baik, jika guru gagal dalam memposisikan diri maka diskusi kelompok kecil tidak akan berjalan secara efektif.

\section{Keterampilan mengadakan penguatan}

Penguatan merupakan suatu bentuk respon yang diberikan oleh guru terhadap siswanya dapat berbentuk verbal maupun non verbal yang merupakan modifikasi tingkah laku guru terhadap tingkah laku siswa yang bertujuan untuk memberikan informasi atau umpan balik bagi siswa atas perbuatannya sebagai suatu tindak dorongan atau koreksi. Seorang calon guru biologi perlu menguasai keterampilan memberikan penguatan karena penguatan merupakan dorongan bagi siswa untuk mengingkatkan perhatiannya.

Mahasiswa calon guru mendapatkan kategori baik pada aspek memberikan penguatan. Pemberian penguatan bertujuan antara lain untuk meningkatkan perhatian siswa terhadap proses pembelajaran, merangsang dan meningkatkan motivasi belajar, serta 
meningkatkan kegiatan belajar dan membina tingkah laku siswa yang prroduktif.

\section{Keterampilan mengadakan variasi}

Variasi merupakan keanekaan yang membuat sesuatu tidak monoton dan berubahubah sesuai dengan kebutuhan. Pemberian variasi dalam pembelajaran diartikan sebagai perubahan pengajran dari yang satu ke yang lain dengan tujuan untuk menghilangkan kebosanan dan kejenuhan siswa dalam menerima bahan pengajaran yang diberikan oleh guru sehingga siswa aktif dan berpartisipasi dalam belajarnya.

Mahasiswa calon guru biologi mendapatkan kategori cukup dalam hal mengadakan variasi. Hal ini menunjukkan bahwa dalam proses pembeljaran mahasiswa calon guru masih cenderung monoton dan tidak ada variasi baik dalam hal penggunaan media pembelajaran maupun dalam interaksi dengan siswa. Mahasiswa calon guru cenderung menggunakan media power point dalam proses pembelajran tanpa disertai dengan media yang lain yang lebih menarik bagi siswa. Selain itu, interaksi yang tercipta masih cenderung interaksi dua arah yaitu guru-siswa-guru, belum tercipta interaksi multi arah.

\section{Keterampilan menutup pelajaran}

Keterampilan menutup pelajaran merupakan adalah salah satu keterampilan dasar mengajar yang penting dikuasai oleh guru. Keterampilan menutup pelajaran adalah kegiatan yang dilakukan untuk mengakhiri proses belajar mengajar. Kegiatan menutup pelajaran bertujuan untuk mengetahui sejauh mana tujuan pembelajaran dapat tercapai dan sejauh mana siswa memahami materi yang telah dipelajari (Putri, 2017).

Mahasiswa calon guru biologi mendapatkan kategori sangat baik dalam aspek menutup pelajaran. Hal ini menunjukkan bahwa mahasiswa calon guru sudah mampu melakukan kegiatan akhir pembelajran dengan sangat baik. Berdasarkan peraturan menteri pendidikan dan kebudayaan no 22 tahun 2016 disebutkan bahwa pada bagian akhir dari pembeljaran harus membuat kesimpulan, melakukan refleksi, melakukan evaluasi, dan menginformasikan materi yang akan dipelajari pada pertemuan yang akan dating.

\section{Simpulan dan saran}

\section{Simpulan}

Berdasarkan hasil penelitian dan analisis data yang telah dilakukan dapat disimpulkan bahwa keterampilan dasar mengajar mahasiswa calon guru program studi pendidikan biologi FKIP UAD berada dalam kategori sangat baik pada aspek membuka pelajaran, bertanya, dan menutup pelajaran. Kategori baik pada aspek penguasaan kelas, menjelaskan, dan memberikan penguatan. Kategori cukup pada aspek melakukan variasi, dan kategori kurang pada aspek memimpin diskusi kelompok kecil.

\section{Saran}

Penelitian perlu dilanjutkan ke dalam tahap real teaching untuk menganalisis seberapa besar peran pengajaran mikro dalam mengembangkan keterampilan dasar mengajar mahasiswa calon guru ketika terjun ke lapangan dalam kegiatan real teaching.

\section{Daftar Pustaka}

Fitri Siti Sundari, Yuli Muliyawati. (2017). Analisis keterampilan dasar mengajar mahasiswa PGSD. Pedagonal Jurnal Ilmiah Pendidikan. Vol 1 nol, halaman 26-36.

Mika Ambarwati. (2016). Analisi keterampilan mengajar calon guru pendidikan matematika pada mata kuliah microteaching. Junal Pedagogia, vol 5 nol, halaman 81-89.

Mulyatun. (2014). Analisis keterampilan dasar mengajar mahasiswa calon guru kimia (studi pada praktik pengalaman lapangan mahasiswa tadris kimia). Jurnal phenomenom, vol 4 no 1 , halaman 79-90.

Nurlaili. (2018). Analisis keterampilan dasar mengajar guru dalam perspektif guru pamong pada mahasiswa prodi PGMI Fakultas Ilmu tarbiyah dan Keguruan UIN Raden Fatah Palembang. Jurnal Ilmiah PGMI, vol 4 nol, halaman 28-40.

Peraturan menteri pendidikan dan kebudayaan Republik Indonesia no 22 tahun 2016 tentang standar proses pembelajran pada pendidikan dasar dan menengah.

Putri Agustina, Alanindra Saputra. (2017). Profil keterampilan dasar mengajar mahasiswa calon guru biologi pada mata kuliah microteaching. Jurnal Bioedukatika, vol v no 1 , halaman 18-28.

Shoffan Shofa . (2016). Keterampilan Dasar Mengajar Microteaching. Surabaya: Mafendra Press. 
Siswanto. (2010). Tingkat penguasaan keterampilan dasar mengajar mahasiswa prodi pendidikan akuntansi fakultas ilmu sosial dan ekonomi UNY. Jurnal pendidikan akuntansi Indonesia, vol VIII, no.2, halaman 41-51.

Sugiono. (2013). Metode Penelitian Kuantitatif, Kualitatif, dan R\&D. Bandung: Alfabeta.
Undang-undang Republik Indonesia no 14 tahun 2005 tentang guru dan dosen.

Uzer Usman. (2005). Menjadi Guru Profesional. Bandung: Rosyda Karya.

Zainal Asril. (2013). Micro Teaching. Depok: Rajawali Press. 